AL IBTIDA: JURNAL PENDIDIKAN GURU MI (2021) Vol 8 (1) : 32-49

DOI: http://dx.doi.org/10.24235/al.ibtida.snj.v8i1.7741

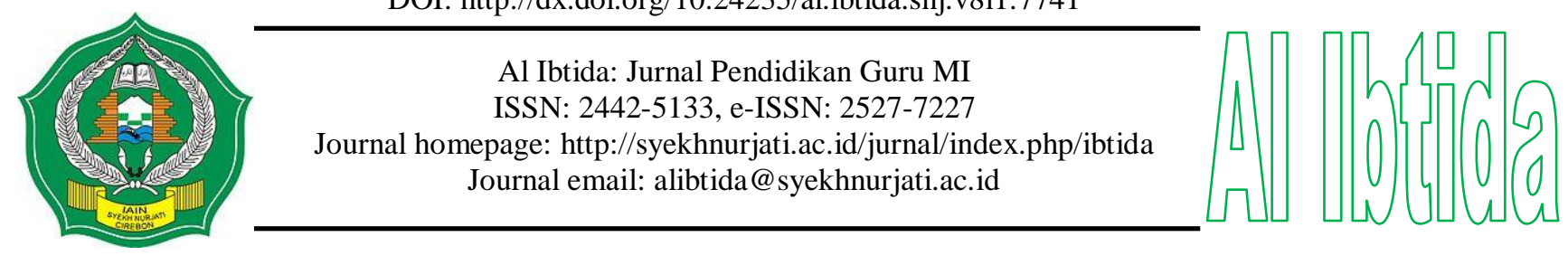

\title{
Learning Designs for the Addition and Subtraction of Two-Digit Numbers based on Realistic Mathematics Education Principles Using Snakes and Ladders Game
}

\author{
Irfan Fauzi* \\ *SD Negeri 093 Tunas Harapan Cijerah, \\ Universitas Pendidikan Indonesia, Bandung, Indonesia \\ Email: if96@upi.edu \\ Rohma Mauhibah** \\ **Elementary Education Study Program, School of Postgraduate, \\ Universitas Pendidikan Indonesia, Bandung, Indonesia \\ Email: rohmamauhibah@upi.edu
}

\author{
Al Jupri*** \\ ***Department of Mathematics Education, Faculty of Mathematics and Science Education, \\ Universitas Pendidikan Indonesia, Bandung, Indonesia \\ Email: aljupri@upi.edu
}

Received: February $14^{\text {th }}, 2021$. Accepted: June 03 ${ }^{\text {rd }}, 2021$. Published: June $27^{\text {th }}, 2021$.

\begin{abstract}
Students have difficulties in understanding addition and subtraction of numbers. These difficulties need to be anticipated in order to find ways to reduce them. This research aims to develop the learning designs for addition and subtraction of two-digit numbers using the Realistic Mathematics Education (RME) approach. The snakes and ladders game was used as the learning media, while the language of arrows was used as the context of learning. Using educational design research, this study involved a total of 29 first graders of one of the elementary schools in Bandung City, Indonesia. The sample in this study was selected using purposive sampling. The data were collected through tests and observations. The results of this research indicated that the learning designs had a positive impact on the students' understanding of the addition and subtraction of two-digit numbers. The students' average score after learning the addition and subtraction of two-digit numbers was 70.62. The principles of Realistic Mathematics Education (RME) are the key to student success in understanding mathematical concepts. This research could be used as a reference for developing mathematics learning designs using the RME approach in elementary schools.
\end{abstract}

Keywords: learning designs, addition and subtraction of numbers, realistic mathematics education. 


\begin{abstract}
Abstrak
Siswa mengalami kesulitan dalam memahami penjumlahan dan pengurangan bilangan. Kesulitan-kesulitan tersebut perlu diantisipasi agar dapat ditemukan cara untuk menguranginya. Penelitian ini bertujuan untuk mengembangkan desain pembelajaran penjumlahan dan pengurangan bilangan dua digit dengan menggunakan pendekatan Realistic Mathematics Education (RME). Permainan ular tangga digunakan sebagai media pembelajaran, sedangkan bahasa panah digunakan sebagai konteks pembelajaran. Menggunakan educational design research, penelitian ini melibatkan total 29 siswa kelas satu salah satu sekolah dasar di Kota Bandung, Indonesia. Sampel dalam penelitian ini dipilih dengan menggunakan purposive sampling. Pengumpulan data dilakukan melalui tes dan observasi. Hasil penelitian ini menunjukkan bahwa desain pembelajaran berpengaruh positif terhadap pemahaman siswa tentang penjumlahan dan pengurangan bilangan dua angka. Nilai rata-rata siswa setelah mempelajari penjumlahan dan pengurangan bilangan dua angka adalah 70,62. Prinsip-prinsip Realistic Mathematics Education (RME) menjadi kunci keberhasilan siswa dalam memahami konsep matematika. Penelitian ini dapat dijadikan acuan untuk mengembangkan desain pembelajaran matematika dengan pendekatan RME di sekolah dasar.
\end{abstract}

Kata kunci: desain pembelajaran, penjumlahan dan pengurangan bilangan, realistic mathematics education.

\title{
INTRODUCTION
}

Mathematics has become an important part of formal education from ancient times until now (Acharya, 2017). According to Deringol (2018), mathematics is needed by children to acquire the knowledge and skills for everyday life. According to Unlu et al. (2017), mathematics is an important subject to be studied by students, because mathematics can encourage various abilities of students. For this reason, mathematics has been taught from elementary education to higher education. However, many students feel that mathematics is a difficult subject to understand (Laurens et al., 2018). Mathematics is taught less attractively so that it is difficult for students to understand it (Suci et al., 2014). As a result, students often feel bored so they do not respond well in learning (Rohmah \& Sutiarso, 2018). Even, according to Turmudi (2008), mathematics has been taught to students informatively, students only get information from the teacher. Thus, their memory is only temporary.

Mathematics teaching is a concern in the education system in various countries (Guinocor et al., 2020); it is the reason why practitioners and educators strive to create an effective mathematics learning system. For students to understand the concept of mathematics completely and thoroughly, several standards must be considered by the teacher in the learning process. According to the National Council of Teachers of Mathematics (2003), mathematics standards are divided into material standards and process standards. Mathematics material standards are related the material that elementary school students need to learn, namely arithmetic, geometry, measurement, and statistics. Mathematics processes standards 
include problem-solving, reasoning, communication, connection, and representation. These standard components need to be included in the mathematics learning process. It is very useful for students as learning subjects.

Numbers are topics within the domain of arithmetic. Numbers are important in learning mathematics in elementary schools (Fauzi \& Suryadi, 2020; Pitta-Pantazi, 2014; Jordan et al., 2010). According to Verschaffel et al. (2007), numbers are important to learn because it relates to the students' real life, serves as a basis for understanding other materials, becomes one of the first materials taught in formal schools. In addition, students' dispositions for mathematics often depend on this material. Counting numbers is the basis for all subsequent integer calculations such as calculating decimals, fractions, comparisons, and percentages. Calculating at a later stage does not only depend on the students' knowledge of number structure and basic numeracy skills, but also on insights into basic numeracy strategies, mathematical attitudes, and general interests in broader mathematics (Treffers \& Buys, 2001).

Based on Kemendikbud (2018), the material for adding and subtracting two-digit numbers has been given to grade 1 elementary school students. Every student should be able to master the material well. However, there were still many students who do not understand the material correctly. Based on the results of research by Sidik \& Wakih (2019), there were still many students who experienced learning difficulties in integer arithmetic operations. Then, according to Watson et al. (2018), students often make mistakes systematically and consistently when calculating addition and subtraction of numbers; the students subtracted a smaller number from a larger number. This is also evidenced by the results of the secondgrade student test in one of the elementary schools in Bandung, where there were 21 out of 30 students who were still unable to add and subtract two numbers correctly. For example, to calculate $45-19=\ldots$, some students answered by subtracting 9 by 5 , then 4 by 1 . So they wrote $45-19=34$.

When students experience learning difficulties, teachers must identify these types of difficulties (Ashlock, 2010). This is important so that teachers can check students' wrong mathematical concepts and correct these concepts according to scientific conceptions. Thus, in the next lesson, the students' difficulties can be resolved well. Teachers need to develop learning designs that focus on reinforcing students' understanding of the material of addition and subtraction of two-digit numbers according to scientific conceptions. In fact, the learning design used is not related to the real conditions of students (Saputri \& Mawardi, 2018). This is what causes students to have difficulty in understanding the various mathematical concepts being taught. In developing a learning design, the teacher should pay attention to various 
components, one of which is the meaning of learning which is built from concrete, realistic problems, and related to the real life of students (Wulandari \& Sulasmono, 2020).

The Realistic Mathematics Education (RME) approach is a solution to make the learning match the real conditions of students. RME was originally from the Netherlands and was inspired by Freudenthal's ideas which explained that mathematics is a human activity (Freudenthal, 1971). The aspect that needs to be understood regarding RME here is realistic, which means "to imagine". The word "realistic" in RME means that the real context that exists in everyday life, formal mathematical context, and imaginary context does not exist in reality but can be imagined (Van den Heuvel-Panhuizen \& Drijvers, 2014).

According to Sembiring (2010), the characteristics of the RME approach are that students are more active in thinking, the context and teaching materials are directly related to the school environment and students, and the role of teachers is more active in designing teaching materials and class activities. Then, according to Clements \& Sarama (2013), the main characteristics of RME include the application of meaningful contexts, the development of models that allow the transformation from contextual to formal mathematics, a recreation of mathematical concepts by students, student and teacher interactions, and the perception of mathematics as an integrated subject. According to Lange (1996), the real context is very important as a starting point in learning mathematics. As De Lange said, the process of developing mathematical concepts and ideas must start with real things, and in the end, it is needed to reflect solutions to the real world. Thus, what has to be done in learning mathematics is to take something from the real world, make mathematics, and then bring it back to the real world. This is called conceptual mathematization. The description of conceptual mathematization is described in Figure 1 below.

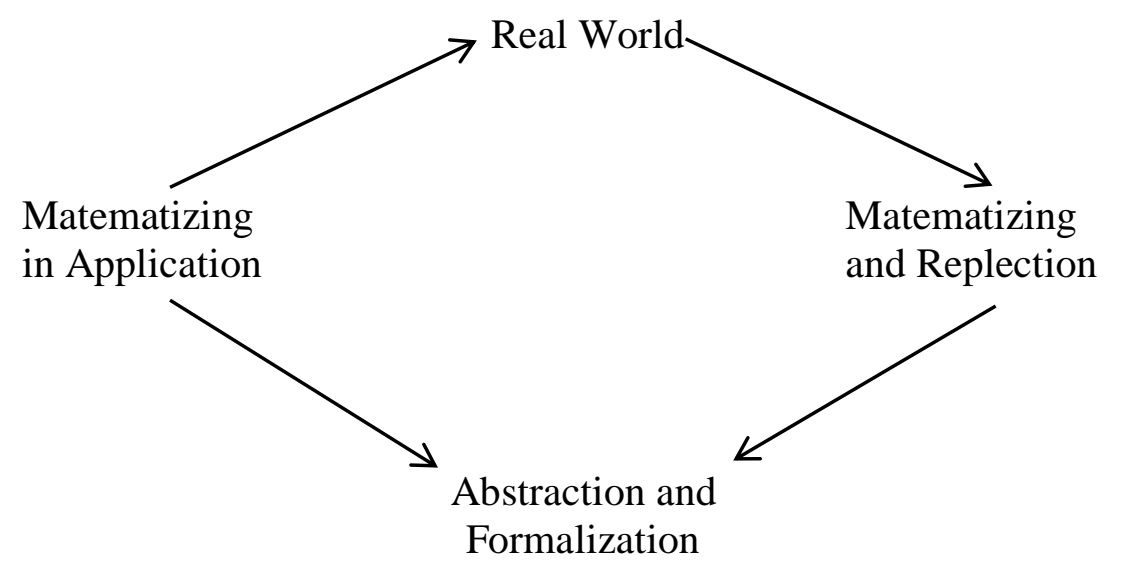

Figure 1. Conceptual Mathematization

According to Kemendikbud (2016), student knowledge in elementary schools needs to be built using the context of life in the community and the student environment. The 
development of student thinking is still at the concrete operational stage and not yet at the formal stage, so the realistic context will help students understand mathematical concepts.

The results of research conducted by Yudistira \& Rabbani (2020) show that RME has a significant impact on student learning outcomes in the material addition and subtraction of numbers. But in their research, they do not explain in detail the kinds of realistic context implemented in the learning process. This research was adopted from the Instituut Ontwikkeling Wiskunde Onderwijs (IOWO) or the Institute for Development of Mathematics Education which developed teaching materials for learning addition and subtraction of numbers entitled "The Bus" (Brink, 1991). By playing the role of the bus, students will naturally realize that adding and subtracting is calculating the total increase and decrease of passengers. A special aspect of this learning design is the presentation of addition and subtraction in the arrow language notation. The results of this research show that the students could master the material of addition and subtraction more quickly through such learning design than through traditional learning (Brink, 1991). Learning addition and subtraction of two-digit numbers in this study cannot be separated from the role of the media. The media used are realistic and close to the lives of students. According to Manalu et al. (2018), the most important factor for achieving successful learning is the use of learning media as teaching materials. The learning media used must be able to attract attention so that students are more motivated and active in participating in the learning process. Media can help students in learning abstract concepts so that it can improve student learning outcomes (Widodo \& Wahyudin, 2018; Maharani \& Dewi, 2015). The media used is a game of snakes and ladders that has been modified using arrows. The snakes and ladders in the grid are replaced with blue and red arrows, so this will lead to the concept of adding and subtracting. Then to support the game, student worksheets are provided to direct the learning process on the concepts being studied.

Understanding the concept of adding and subtracting numbers is very important for students (Torbeyns et al., 2016). This is the basis for understanding other material, one of which can be done by using various approaches. Realistic Mathematics Education (RME) approach has been widely applied to the mathematics learning processes at all levels of education, and various studies have also shown that RME is used to develop various skills, such critical and creative thinking (Dhayanti et al., 2018), and productive dispositions (Haji et al., 2019), or there are those who combine Realistic Mathematics Education (RME) with various other theories and approaches such as Ardiyani \& Gunarhadi (2018) which combines Cooperative Learning, Das (2020) combines learning theory with Vygotsky, and Nursyahidah 
et al (2018) combines ethnomathematics. These various studies have shown positive results on mathematics learning. The use of the Realistic Mathematics Education (RME) approach can improve learning outcomes and various skills in learning mathematics. In this research, the learning design uses the Realistic Mathematics Education (RME) approach. The game of snakes and ladders is used as a learning medium to replace the context of the bus described by Instituut Ontwikkeling Wiskunde Onderwijs (IOWO), this is because the game is very familiar among Indonesian students. In the snake and ladder game, a step forward is an addition operation. While stepping down when stepping on with a snake's tail is a reduction operation. Students usually perceive that mathematics is very difficult to understand because it is full of symbols, notations, and is abstract. But after being given this learning design, students will change their views and will see that learning mathematics becomes more meaningful and fun. This research is different from previous studies both in terms of the media used and in the learning process. Based on this explanation, this research aims to develop a learning design for addition and subtraction of two-digit numbers using the Realistic Mathematics Education (RME) approach, with the game of snakes and ladders as the learning media. The context of learning uses the language of arrows. It is hoped that this research can facilitate students in understanding the concept of adding and subtracting twodigit numbers correctly. This research can also be a reference for various parties including teachers in planning, implementing, and evaluating mathematics learning using the Realistic Mathematics Education (RME) approach.

\section{METHODS}

This research used educational research design, it is reasonable because this research aims to develop a learning design on addition and subtraction of two-digit numbers. The model used in this study refers to Plomp (2013). There are three stages in the design research used including: preliminary research, analysis of material and curriculum and analysis of student learning difficulties on the material of addition and subtraction of two-digit numbers; prototyping stage, making a learning design prototype, holding discussions with experts to obtain theoretical and practical knowledge suggestions, making revisions based on expert suggestions, and implementing learning designs; and assessment phase, the result of implementation that has been observed as the basis for evaluating and revising the learning design for the addition and subtraction of two-digit numbers.

The data collection of this research was conducted at one of the public elementary schools in Bandung. The population in this study was all grade 1 students at the school. The consideration in selecting this population is that these elementary school students go through 
an admission system determined by the local government through tests and zoning. Therefore, the researcher argues that students in each class have the same basic characteristics and abilities. The sample in this study was determined through purposive sampling. The sample used was 29 students in grade 1 who received a learning design trial of addition and subtraction of two-digit numbers. The sample is determined based on the basic abilities possessed by the class which are equivalent to other class 1 in the school. The facilities and the curriculum used is the same in each class. Therefore, the class is considered representative of the population in this study.

The steps in the data collection are as follows: 1) the test is given to grade 2 students who have received the concept material of addition and subtraction of two-digit numbers, the goal is to see the suitability of the concept for the students. The test was also given to grade 1 student to see the impact of the implementation of the learning design for addition and subtraction of two-digit numbers; and 2) observation is carried out to see the suitability of the learning design developed with the implementation of the design. Meanwhile, the aspects observed are activities carried out by students, things of special concern, records of success, and things that must be improved in the learning process. This observation is the basis for revising the learning design as a form of output from this research.

The steps in the data analysis in this study are as follows: 1) test, the researcher analyzes both quantitative and qualitative data. The quantitative data obtained were analyzed using descriptive statistics; the aim was to describe the subjects studied through data obtained from the sample or population (Susetyo, 2017). The descriptive statistic used is the average score of the students in answering the 2-digit number addition and subtraction questions after testing the design. Qualitative data analysis is done by recording all student responses who answer questions, classifying and identifying types of student answers, and analyzing in detail the students' answers; and 2) observation, researchers take videos and photos of learning activities, then note important aspects that arise, provide comments and assess the results of observations that have been made. The flow of this research is described in Figure 2. 
Irfan Fauzi, Rohma Mauhibah, Al Jupri, Learning Designs for the Addition and Subtraction...

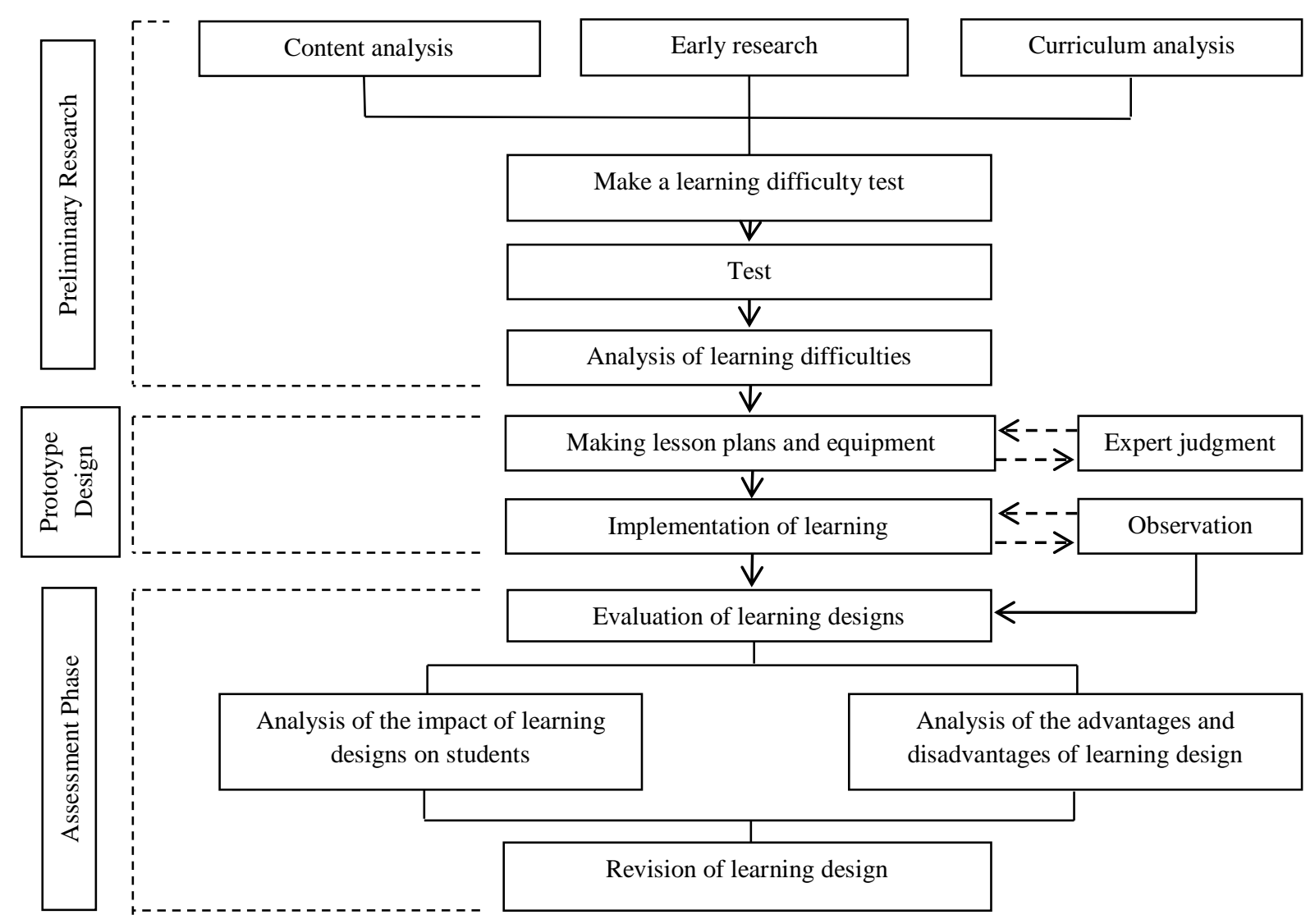

Figure 2. The Flow of Research

\section{RESULTS AND DISCUSSION}

The results and discussion in this research are presented according to the stages of the model developed by Plomp (2013). Each stage of the research is described in detail below.

\section{Preliminary Research}

Based on the results of tests carried out on grade 2 students at one of the elementary schools in Bandung, those students still have difficulty in understanding the addition and subtraction of two-digit numbers. The results of the test have been explained in Mauhibah \& Karso (2020) in Table 1 below.

Table 1. The Results of Student Answers

\begin{tabular}{lcc}
\hline Question & Correct & Wrong \\
\hline 1. $12+45=$ & 26 & 2 \\
2. $17+12=$ & 23 & 5 \\
3. $46-28=$ & 6 & 22 \\
4. $79-32=$ & 26 & 2 \\
5. $15+7-9=$ & 16 & 12 \\
\hline
\end{tabular}

From the table 1, students have difficulty especially in subtracting numbers. When students are faced with questions $46-28=\ldots$, students subtract each number decreasingly, as shown in Figure 3. 


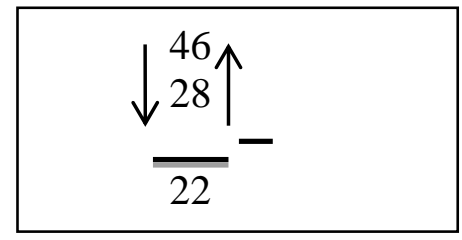

Figure 3. The Way Students Often Do

But, if the number cannot be subtracted (6-8), as shown in Figure 3, students will reverse it to be 8-6. This method impacts on students' wrong answers. This error is understandable because the learning activities are still mechanistic. Mathematics is taught formally, separated between topics; and mathematical content is structured based on the structure of mathematics as a scientific discipline. Students learn mathematics step by step, and follow the method that the teacher teaches in solving mathematical problems (Jupri, 2017). For example, the teacher gives formal questions such as $3+5=8$. After that, students will be given similar exercises repeatedly so that they are expected to be able to avoid mistakes. Even though, according to Brink (1991) low-grade students need a physical activity that is familiar to build an understanding of mathematical operations.

The addition and subtraction of two-digit numbers are important material to be taught so that students understand other numbers of material. Based on the results of a study from Kemendikbud (2018), at least the minimum indicators that must be mastered by students about addition and subtraction of two numbers in grade 1 elementary school are: students can add and subtract 1-99, students can solve daily problems related to addition and subtraction from 1-99, and students can find relationships between numbers which are the result of addition and subtraction operations from 1-99.

Usually, the number line is one of the contexts of how to teach the material of addition and subtraction of numbers. In the number line model, the addition sign indicates the move to the right and the subtraction operation sign shows the left direction. The "+" sign in front of the integer means keeping the direction (moving to the right), while the "_" on the other hand represents moving in the opposite direction (to the left). However, some researchers criticize giving meaning to the "_“ movement when performing addition and subtraction operations on number lines that require rules (Isik, 2018). The material of addition and subtraction of twodigit numbers should not be directly taught in notation using the sign "+" or "-_, because this will have an impact on the meaning of learning. Students need to build complete knowledge and be guided to find that the concept of adding is "+" and subtract is "_". The concept must be built according to real-life situations. Therefore, this will facilitate the students' way of 
thinking about integers or the conceptual model of integers and it will help students connect other things in the learning process.

\section{Prototype Design}

Students' difficulties in addition and subtraction two-digit numbers need to be anticipated by making learning designs. The design made in this research used the RME approach with snake and ladder media. Some of the activities conducted at this stage are: making lesson plans using the RME approach on the concept material of addition and subtraction from numbers 1-99; and preparing other learning equipment in the form of media, worksheets, evaluation sheets, and observation sheets.

The media used is a game of snakes and ladders. The media has been modified and is different from other snakes and ladders, it can be seen in Figure 4 below.

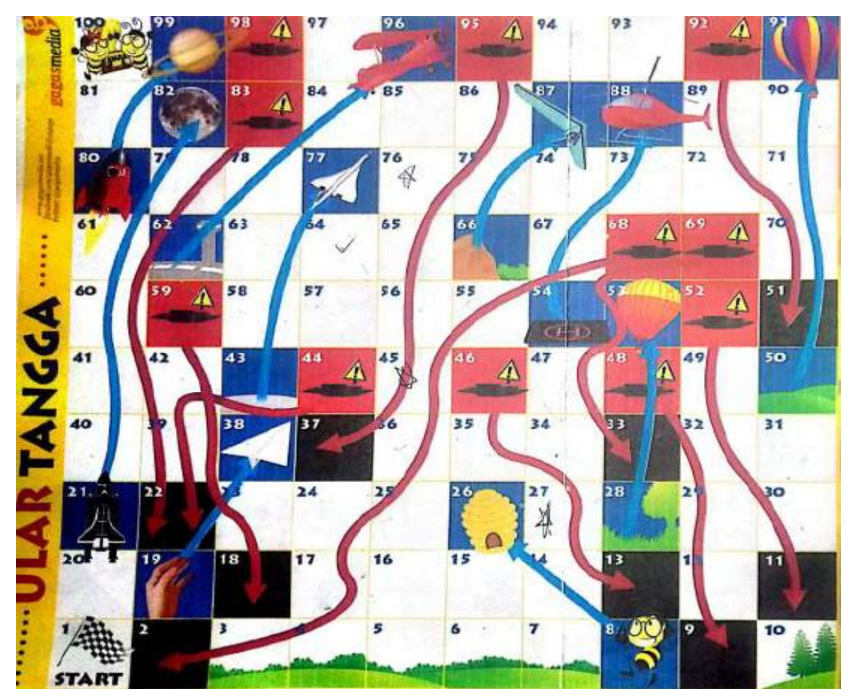

Figure 4. Snake and Ladder Game Media (Mauhibah, 2012)

Students are also given worksheets that they must fill in when playing with snakes and ladders. Student worksheets can be seen in Figure 5 below.

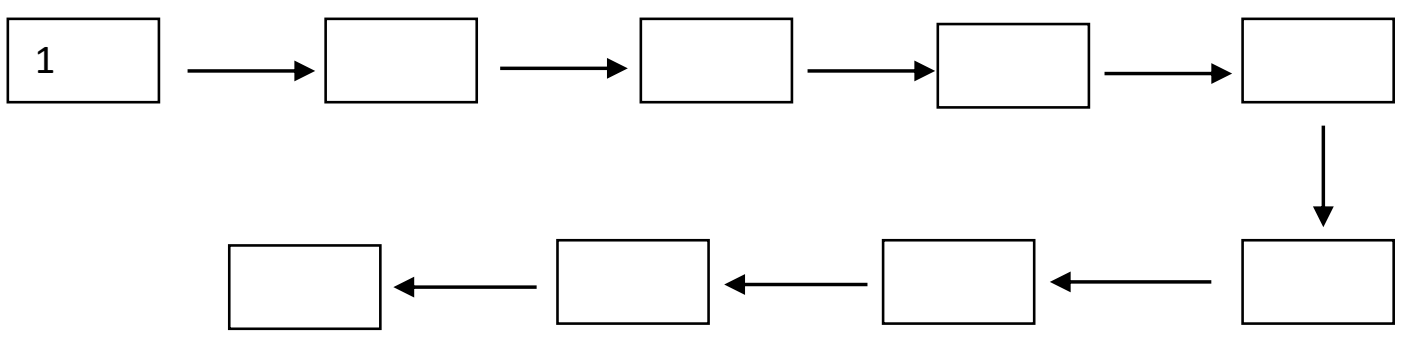

Figure 5. Student Worksheets

Students will fill in the number according to the die that appears as the sum above the arrow by including the symbol $(+\ldots)$. Then, the student writes in the square the number of numbers after the student moves according to the die. If a student steps on the blue arrow, the student will move according to the designated place and fill in the sign $(+\ldots)$ after they move. 
When a student steps on the red arrow, the student will move according to the designated place and fill in the sign (-...) after they move.

After discussing and revising the design, the researcher implemented the learning design to see the impact of the learning design on students' understanding of the material of addition and subtraction of two-digit numbers in a grade 1 elementary school.

During the learning process, students were introduced to the game of snakes and ladders. All students already knew how to play the snake and ladder game and this made them happy. Indirectly they learned while playing. This game involves a didactic contract. According to Brosseaou (2002), this didactic contract regulates the social responsibility that underlies the devolution process, namely the transfer of problem-solving from the teacher to the student; the teacher acts as a supervisor who sees how the didactic contract works properly, if the didactic contract does not work well, the teacher can take over to rectify this.

When students play, students also began to remind their friends who forgot to write down the steps to play in the worksheets or helping their friends to count each step in the snake and ladder game plot. This discussion process went well until the snake and ladder game ended. This principle is described by Piaget (Müller et al., 2015), social interaction plays a role in developing students' intellectual processes; Piaget also explained that children's cognitive development is influenced by social interactions. By the level of student development, this learning design is also at the concrete operational stage.

This learning principle is also discussed by David Ausubel who explains that the use of contextual problems that are close to the student's environment can stimulate students to be actively involved in learning. According to Mayer (2001), meaningful learning happens when students can use the knowledge they learn to solve problems and to understand new concepts by transferring their knowledge to new situations and problems.

Overall, learning addition and subtraction of two-digit numbers using snake and ladder media can be implemented well. Students were very enthusiastic in playing a game of snakes and ladders. Some students began to discover the concept of addition and subtraction, but some students were still confused and had difficulty in operating numbers. This can be seen from the results of the student worksheet analysis.

Students discover the concept of adding and subtracting two-digit numbers by running the pieces in each square, when stepping on the blue arrow (up) the students count one by one the squares that are passed and vice versa when stepping on the red arrow. This can be seen in Figure 6. 


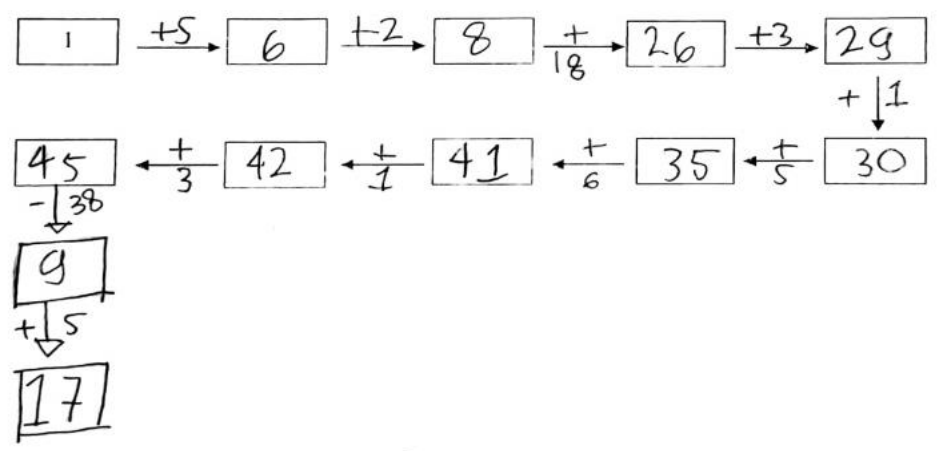

Figure 6. Students Find the Concept of Addition and Subtraction

Students find the concept of addition and subtraction, but when they find the blue arrow (up). Students do not count the number of squares that are traversed until it rises on the square where the arrowheads are, and vice versa when stepping on the red arrow (down). This can be seen in Figure 7 below.

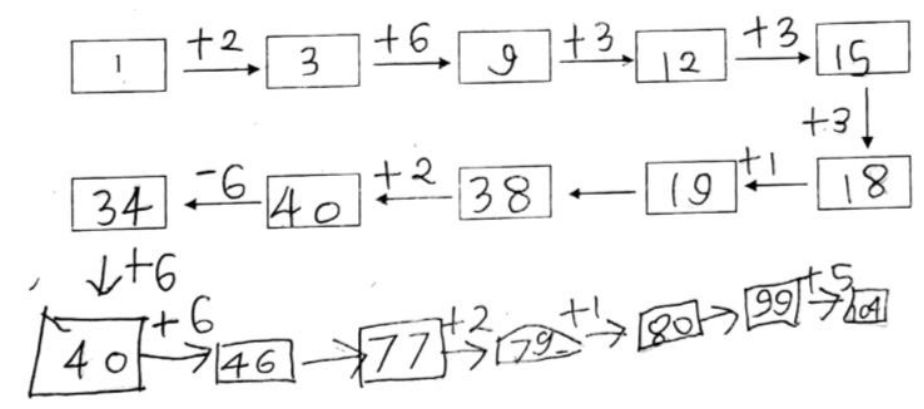

Figure 7. Students Do Not Enter Numbers after Going Up or Down

When the student steps on the blue or red arrow, the student counts each row in the snake and ladder. This can be seen in Figure 8 below.

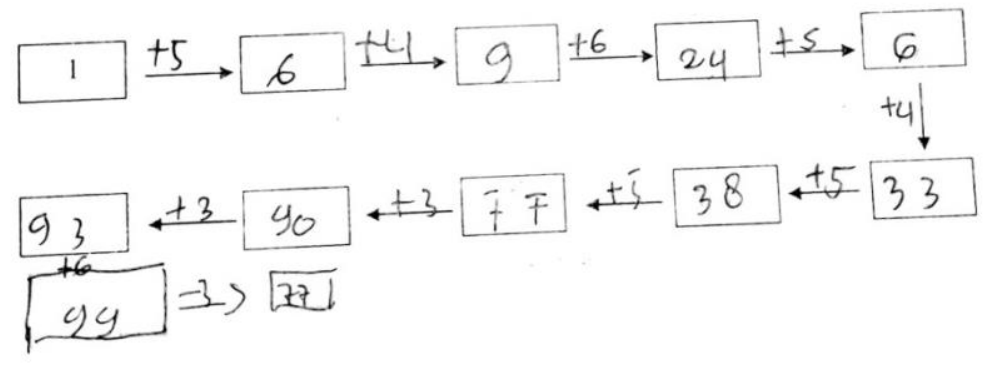

Figure 8. Counting Each Line when Stepping on an Arrow

Students miscalculate numbers on the worksheet. This can be seen in Figure 9 below.

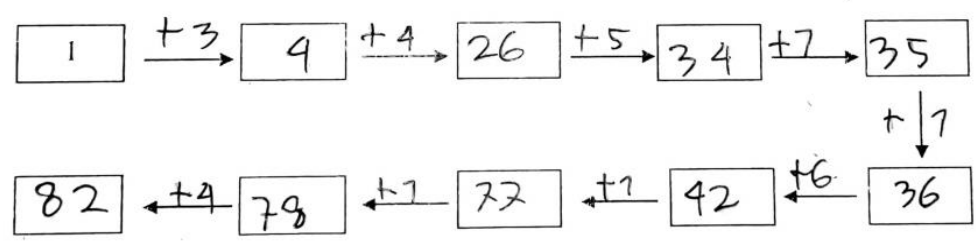

Figure 9. Students Miscalculated 
Students do not understand play instructions, so they have difficulty filling out worksheets. This can be seen in Figure 10 below.

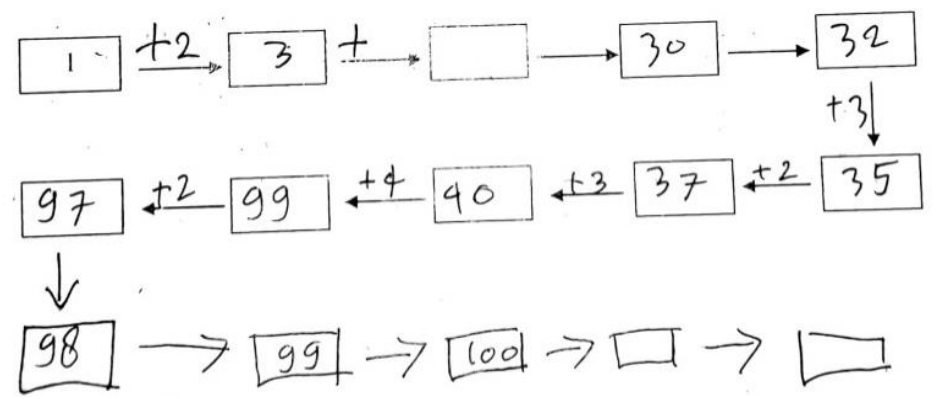

Figure 10. Students Have Difficulty Filling out Worksheets

\section{Assessment Phase}

When given a learning evaluation, the results showed positive results. The student's average score was 70.62. This shows that the learning design had an impact on students' understanding of addition and subtraction of two-digit numbers. However, there were still students who had difficulty understanding the material. The results of student scores are described in detail in Figure 11 below.

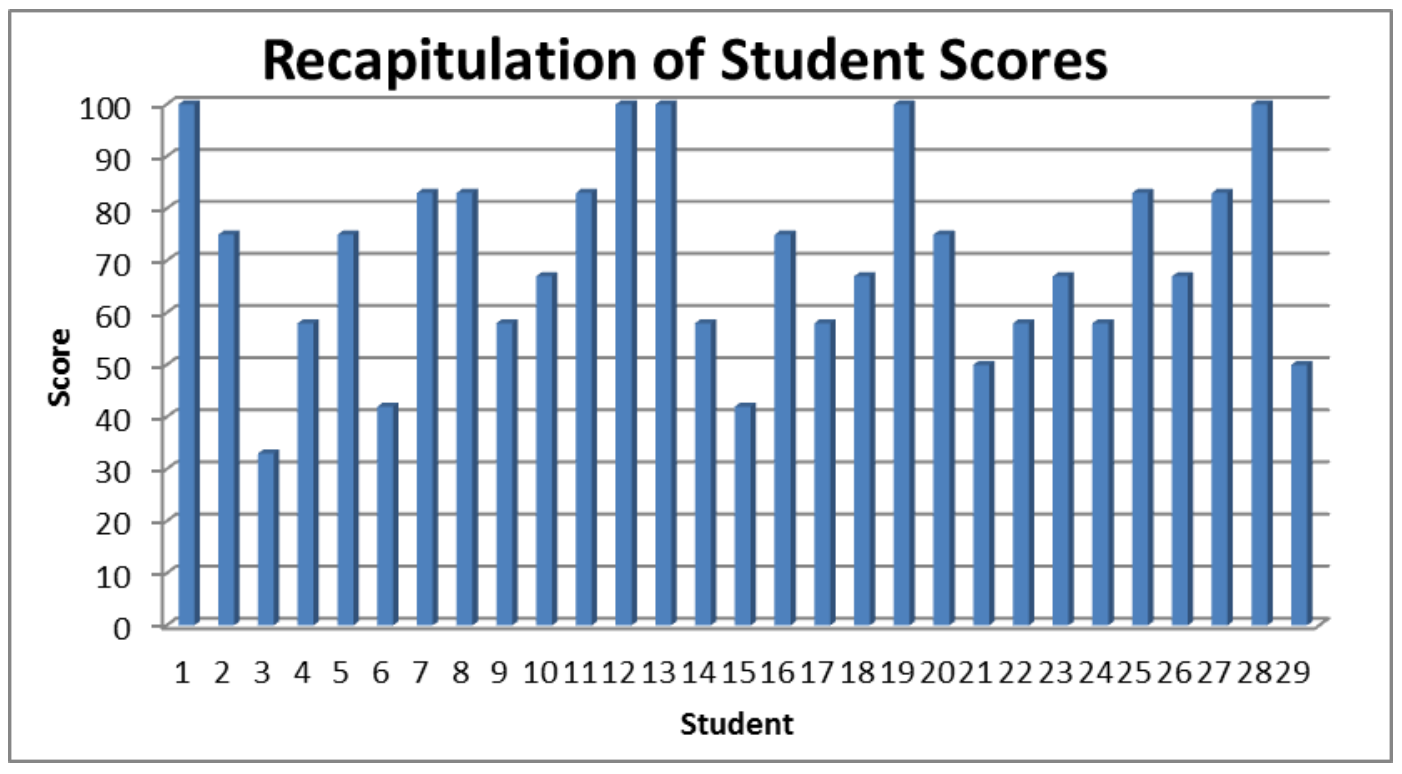

Figure 11. Recapitulation of Student Scores

Learning designs that have been implemented are evaluated based on observations made by several observers. The evaluation results are: 1) when the teacher explained the rules for playing snakes and ladders, some students did not pay attention. Several groups asked about the rules for playing snakes and ladders during the game. Then, some students already knew the rules of the game of snakes and ladders; they immediately played the game before being instructed by the teacher. They even made their own rules, for example, players could walk when the dice number six, even though this was not explained in the rules of play; 2) some 
students had difficulty in writing down the steps on a worksheet. This was because some students did not understand the game instructions. An example was when a student step on the red arrow which means down. Students counted each row in the square. The students should count one by one the squares that were passed to the head of the blue arrow; 3) when the teacher appointed students to explain the story of the snake and ladder game, some students did not pay attention to their friends' explanations. Some students played in their groups; and 4) when the teacher gave evaluation questions, there were still students who had difficulty working on them. Even, there were students who asked questions they did not understand. There were also students who asked for pictures of the snake and ladder game to solve the question.

There are some aspects that need to be improved: 1) the large snake and ladder media need to be posted in front of the class so that will help the learning process; 2) the instructions for playing snakes and ladders must be clarified so that all students can understand the game; this is also related to didactic contracts (Brosseaou, 2002) which must be implemented properly; 3 ) the teacher must guide students in finding the concept of addition and subtraction, especially when students step on the blue arrow (up) and the red arrow (down) in the snake and ladder game. At this stage students find difficulty, or in Piaget's theory, students experience disequilibrium; this occurs when students have to understand the context of the problem through new information (Lovatt \& Hedges, 2014). The impact is that students experience difficulties in dealing with these conditions. To overcome this, it can be done by providing some guidance/scaffolding. Scaffolding is providing assistance to students who find it difficult to learn, and after that students can solve the problems independently (Baxter \& Williams, 2010). Scaffolding is part of a learning strategy to facilitate students to learn effectively (Lin et al., 2012). When the scaffolding role goes well, students will experience equilibrium or balance in understanding the context of a particular problem, this is where the learning process occurs.; 4) after students explain in front of the class, the teacher must strengthen the concept of addition and subtraction by explaining classically; 5) the teacher must focus on learning and ask students to follow it well; and 6) the learning design that has been implemented needs to be reinforced by discussing the material that has been taught in the next lesson so that students' understanding will be more comprehensive. 
Irfan Fauzi, Rohma Mauhibah, Al Jupri, Learning Designs for the Addition and Subtraction...

\section{CONCLUSION}

This research indicated that the learning design of addition and subtraction of two-digit numbers using Realistic Mathematics Education has a positive impact on students' understanding. Based on the results of the evaluation after implementation, the students' average score was 70.62. The learning design that has been implemented serves as the basis for the students' understanding of the concepts of addition and subtraction of two-digit numbers. This design can be implemented in the learning of addition and subtraction of twodigit numbers in grade 1 elementary school. This research is expected to make a contribution to education in Indonesia, especially for the mathematics learning in elementary schools. This research can be used as a reference for conducting other research in mathematics education using Realistic Mathematics Education (RME). This learning design is an alternative in mathematics education research, especially in developing learning on the concept of addition and subtraction of two-digit numbers in elementary schools. This design can be refined and redeveloped for a better design in the future.

\section{REFERENCES}

Acharya, B. R. (2017). Factors Affecting Difficulties in Learning Mathematics by Mathematics Learners. International Journal of Elementary Education, 6(2), 8-15. https://doi.org/10.11648/j.ijeedu.20170602.11.

Ardiyani, S. M., \& Gunarhadi, R. (2018). Realistic Mathematics Education in Cooperative Learning Viewed from Learning Activity. Journal on Mathematics Education, 9(2), 301-310. https://doi.org/10.22342/jme.9.2.5392.301-310.

Ashlock, R. B. (2010). Errors Patterns in Computation: Using Error Patterns to Help Each Student Learn. $10^{\text {th }}$ eds., Allyn \& Bacon, Boston, MA.

Baxter, J. A., \& Williams, S. (2010). Soccial and Analytic Scaffolding in Middle School Mathematics: Managing The Dilemma of Telling. Journal of Mathematics Teacher Education, 13(1), 7-26. https://doi.org/10.1007/s10857-009-9121-4.

Brink, V. den. (1991). Realistic Arithmetic Education for Young Children. in L. Streefland (Ed.), Realistic Mathematics Education in Primary School: On the Occasion of the Opening of the Freudenthal Institute. Utrecht: Freudhental Institute.

Brosseaou, G. (2002). Theory of Didactical Situation in Mathematics. New York, Boston, Dordrecht, London, Moscow: Kluwer Academic Publishers.

Clements, D. H., \& Sarama, J. (2013). Rethinking Early Mathematics: What is Research based Curriculum for Young Children? In L. D. English \& J. T. Mulligan (Eds.), Reconceptualizing Early Mathematics Learning (pp. 121-147). Dordrecht: Springer.

Das, K. (2020). Realistic Mathematics \& Vygotsky's Theories in Mathematics Education. Shanlax International Journal of Education, 9(1), 104-108. https://doi.org/10.34293/education.v9i1.3346.

Deringol, Y. (2018). Primary School Students' Mathematics Motivation and Anxieties. 
Irfan Fauzi, Rohma Mauhibah, Al Jupri, Learning Designs for the Addition and Subtraction...

Cypriot Journal of Educational Sciences, 13(4), 537-548. https://doi.org/10.18844/cjes.v13i4.3462.

Dhayanti, D., Johar, R., \& Zubainur, C. M. (2018). Improving Students' Critical and Creative Thinking through Realistic Mathematics Education using Geometer's Sketchpad. JRAMathEdu (Journal of Research and Advances in Mathematics Education), 3(1), 25. https://doi.org/10.23917/jramathedu.v3i1.5618.

Fauzi, I., \& Suryadi, D. (2020). The Analysis of Students' Learning Obstacles on the Fraction Addition Material for Five Graders of Elementary Schools. Al Ibtida: Jurnal Pendidikan Guru MI, 7(1), 33-45. https://doi.org/10.24235/al.ibtida.snj.v7i1.6020.

Freudenthal, H. (1971). Geometry between the Devil and The Deep Sea. Educational Studies in Mathematics, 3, 413-435.

Guinocor, M., Almerino, P., Mamites, I., Lumayag, C., Villaganas, M. A., \& Capuyan, M. (2020). Mathematics Performance of Students in a Philippine State University. International Electronic Journal of Mathematics Education, 15(3), 1-14. https://doi.org/10.29333/iejme/7859.

Haji, S., Yumiati, Y., \& Zamzaili, Z. (2019). Improving Students' Productive Disposition through Realistic Mathematics Education with Outdoor Approach. JRAMathEdu (Journal of Research and Advances in Mathematics Education), 4(2), 101-111. https://doi.org/10.23917/jramathedu.v4i2.8385

Isik, C. (2018). Analyzing Problems Posed by Prospective Teachers Related to Addition and Subtraction Operations with Integers. Higher Education Studies, 8(3), 1-14. https://doi.org/10.5539/hes.v8n3p1.

Jordan, N. C., Glutting, J., \& Ramineni, J. (2010). The Importance of Number Sense to Mathematics Achievement in First and Third Grades. Learning and Individual Differences, 20(2), 82-88. https://doi.org/https://doi.org/10.1016/j.lindif.2009.07.004.

Jupri, A. (2017). From geometry to algebra and vice versa: Realistic mathematics education principles for analyzing geometry tasks. AIP Conference Proceedings, 1830. https://doi.org/10.1063/1.4980938

Kemendikbud. (2016). Permendikbud Nomor 20 Tahun 2016 tentang Standar Kompetensi Lulusan Pendidikan Dasar dan Menengah. Jakarta: Kemendikbud.

Kemendikbud. (2018). Permendikbud Nomor 37 Tahun 2018 tentang Perubahan atas Permendikbud Nomor 24 Tahun 2016 tentang Kompetensi Inti dan Kompetensi Dasar Pelajaran Pada Kurikulum 2013 pada Pendidikan Dasar dan Pendidikan Menengah. Jakarta: Kemendikbud.

Lange, J. de. (1996). Using and applying mathematics in education. In A.J. Bishop et al (Ed.), International Handbook of Mathematics Education (pp. 49-97). Netherlands: Kluwer Academic Publishers.

Laurens, T., Batlolona, F. A., Batlolona, J. R., \& Leasa, M. (2018). How Does Realistic Mathematics E(RME) Improve Students' Mathematics Cognitive Achievement? Eurasia Journal of Mathematics, Science and Technology Education, 14(2), 569-578. https://doi.org/10.12973/ejmste/76959

Lin, T., Hsu, Y., Lin, S., Changlai, M., Yang, K., \& Lai, T. (2012). A Review of Empirical Evidence on Scaffolding for Science Education. International Journal of Science and Mathematics Education, 10, 437-355.

Lovatt, D., \& Hedges, H. (2014). Children's Working Theories: Invoking Disequilibrium. 
Irfan Fauzi, Rohma Mauhibah, Al Jupri, Learning Designs for the Addition and Subtraction...

Early Child Development and Care, 185(6), 909-925. https://doi.org/10.1080/03004430.2014.967688.

Maharani, D. W., \& Dewi, N. R. (2015). The Implementation of Science Inquiry-based Website Oriented by Cultural Deviance Solution to Instill Students' Character and Independence. Jurnal Pendidikan IPA Indonesia, 4(1), 25-30. https://doi.org/10.15294/jpii.v4i1.3497.

Manalu, H. C. B., Silaban, S., \& Hutabarat, W. (2018). The Development of Teaching Materials Stoichiometric Integrated Multimedia Easy Sketch. 3rd Annual International Seminar on Transformative Education and Educational Leadership (AISTEEL 2018) The, 200, 352-356. https://doi.org/10.2991/aisteel-18.2018.77

Mauhibah, R. (2012). Aku Pintar Matematika SMP. Jakarta: Gagas Media.

Mauhibah, R., \& Karso. (2020). Student Difficulties in Addition and Subtraction of Two Digit Numbers. The 2nd International Conference on Elementary Education, 2(1), 618-623.

Mayer, R. (2001). The Cognitive Process Dimension. In A. L. Anderson, D. Krathwohl, P. Airasian, K. Cruikshank, R. Mayer, P. Pintrich, J. Raths and M. Wittrock (Ed.), Taxonomy for Learning, Teaching, and Assessing: A Revision of Bloom's Taxonomy of Educational Objectives. New York: Longman.

Müller, Eycke, \& Baker. (2015). Piaget's Theory of Intelligence. In S. Goldstein, D. Princiotta, \& J. A. Naglieri (Eds.), Handbook of Intellegence. https://doi.org/https://doi.org/10.1007/978-1-4939-1562-0.

National Council of Teachers of Mathematics. (2003). The Use of Technology in Learning and Teaching of Mathematics. http://nctm.org/about/position_statements/position_statement_13.html.

Nursyahidah, F., Saputro, B. A., \& Rubowo, M. R. (2018). A Secondary Student's Problem Solving Ability in Learning Based on Realistic Mathematics with Ethnomathematics. JRAMathEdu (Journal of Research and Advances in Mathematics Education), 3(1), 13-24. https://doi.org/10.23917/jramathedu.v3i1.5607.

Pitta-Pantazi, D. (2014). Number Teaching and Learning. In S. Lerman (Ed.) Encyclopedia of Mathematics Education. London: Springer.

Plomp, T. (2013). Educational Design Research. In T. Plomp \& N. Nieveen (Eds.), Educational Design Research (pp. 1-206). Enschede, The Netherlands: Netherlands Institute for Curriculum Development. https://doi.org/10.1007/978-1-4614-3185-5_11.

Rohmah, M., \& Sutiarso, S. (2018). Analysis Problem Solving in Mathematical Using Theory Newman. Eurasia Journal of Mathematics, Science and Technology Education, 14(2), 671-681. https://doi.org/10.12973/ejmste/80630.

Saputri, W. A. T., \& Mawardi, M. (2018). Pengembangan Desain Pembelajaran Tematik Integratif Berbasis Pendekatan Contextual Teaching and Learning (CTL) Kelas 4 Sekolah Dasar. Jurnal Ilmiah Pendidikan Dasar, 4(2), 104-114. https://doi.org/10.30659/pendas.4.2.104-114.

Sembiring, R. K. (2010). Pendidikan Matematika Realistik Indonesia (PMRI): Perkembangan dan Tantangannya. Journal on Mathematics Education, 1(1), 11-16. https://doi.org/10.22342/jme.1.1.791.11-16.

Sidik, G. S., \& Wakih, A. A. (2019). Kesulitan Belajar Matematik Siswa Sekolah Dasar pada Operasi Hitung Bilangan Bulat. Naturalistic: Jurnal Kajian Penelitan Dan Pendidikan Dan Pembelajaran, 4(1), 461-470. https://doi.org/10.35568/naturalistic.v4i1.633. 
Suci, A., Martha, D., \& Basuki, F. H. (2014). Perancangan Game Edukatif ( Perhitungan Matematika Sederhana ). Jurnal Komputer Bisnis, 456, 29-34.

Susetyo, B. (2017). Statistika untuk Analisis Data Penelitian. Refika Aditama.

Torbeyns, J., Peters, G., De Smedt, B., Ghesquière, P., \& Verschaffel, L. (2016). Children's Understanding of the Addition/Subtraction Complement Principle. The British Journal of Educational Psychology, 86(3), 1-15. https://doi.org/10.1111/bjep.12113.

Treffers, \& Buys, K. (2001). Children Learn Mathematics: Calculation up to One Hundred. Utrecht: Freudenthal Institute Utrecht University.

Turmudi. (2008). Landasan Filsafat dan Teori Pembelajaran Matematika (Berparadigma Eksploratif dan Investigatif). Jakarta: Leuseur Cipta Pustaka.

Unlu, M., Ertekin, E., \& Dilmac, B. (2017). Predicting Relationships between Mathematics Anxiety, Mathematics Teaching Anxiety, Self-efficacy Beliefs towards Mathematics and Mathematics Teaching. International Journal of Research in Education and Science, 636-636. https://doi.org/10.21890/ijres.328096.

Van den Heuvel-Panhuizen, M., \& Drijvers, P. (2014). Realistic Mathematics Education. In S. Lerman (Ed.), Encyclopedia of Mathematics Education. Encyclopedia of Mathematics Education. Dordrecht, Heidelberg, New York, London: Springer.

Verschaffel, L., Greer, B., \& De Corte E. (2007). Whole Number Concepts and Operations. In: Lester FK (ed.) Second Handbook of Research on Mathematics Teaching and Learning (pp.557-628). IAP: Charlotte.

Watson, S. M. R., Lopes, J., Oliveira, C., \& Judge, S. (2018). Error Patterns in Portuguese Students' Addition and Subtraction Calculation Tasks: Implications for Teaching. Journal for Multicultural Education, 12(1), 67-82. https://doi.org/10.1108/JME-012017-0002.

Widodo, S., \& Wahyudin. (2018). Selection of Learning Media Mathematics for Junior School Students. Turkish Online Journal of Educational Technology - TOJET, 17(1), 154-160.

Wulandari, A. I., \& Sulasmono, B. S. (2020). Pengaruh Pendekatan Pendidikan Matematika Realistik (PMR) terhadap Hasil Belajar Siswa Sekolah Dasar. Jurnal Pendidikan dan Pengajaran Guru Sekolah Dasar (JPPGuseda), 3(1), 78-82. https://doi.org/10.31004/basicedu.v5i2.878.

Yudistira, I., \& Rabbani, S. (2020). Penggunaan Metode Pembelajaran Realistics Mathematic Education (RME) pada Operasi Hitung Penjumlahan dan Pengurangan Bsiswa Kelas I SD. COLLASE (Creative of Learning Students Elementary Education), 3(5), 193-200. 